\title{
Psychological Pressures Affecting Social Studies Teachers at Ma'an Directorate of Education
}

\author{
Dr. Khalid abedlraman al_atyat \\ Department of Curriculums \& Instruction, Faculty of Educational Sciences \\ Al-Hussien Bin Talal University, Jordan \\ E-mail: hani@ahu.edu.jo \\ Dr. hani hatmel obeidat \\ Department of Curriculums \& Instruction, Faculty of Educational Sciences \\ Al-Hussien Bin Talal University, Jordan \\ E-mail: hatmalko@yahoo.com
}

\begin{abstract}
The study aims at identifying the psychological pressures that affect Social Studies (SS) teachers. In order to attain the objective of the study a questionnaire composed of 35 items representing the major psychological stress has been prepared. Moreover, the validity and reliability of such items have been verified. The study sample comprises 76 male and female teachers. The study concludes that the level of pressure affecting social studies teachers reaches $88.66 \%$. Some of the major pressures found are the constant change of study books, students insulting teachers, the negative perspective of society toward the teacher, low and insufficient salaries and the large number of daily study classes. Significant statistical differences have been found due to gender variable and in the favor of male teachers. Findings also revealed significant differences due to teaching experience variable.
\end{abstract}

Keywords: Psychological pressures, Social studies teachers, Ma'an Directorate of Education

\section{Introduction}

The era we live in is an informational one. If the society we aim to be is a society of knowledge, a teacher becomes the leader, the guide and the director since teachers enjoy a number of merits gained through their relations with all kinds of people; the teacher is a complementary part for every family because he/she teaches our sons and daughters. Therefore, on the grounds of his/her occupation, specialization and connection, a teacher is a leader of society, so we must provide self-security and job security for teachers, lessen the psychological pressures which they face and which can affect their role negatively.

The teacher is an expert employed by society to achieve its educational purposes. He plays the main role of encouraging the educated to practice the diverse activities of socialization since his connections to students are effective and he is the good example for students within classrooms. The teacher is the backbone of education. The educated is as good as his teacher. (Alrashdan and Ja'aneeni, 1994).

The teacher has a message he must deliver to his students: he has to develop them mentally and contribute to the growth of their personalities and to the creation of their cultural identities or activate their interaction with the local community (Ali, 2007).

Consequently, the teacher has to have a constant desire for learning and education, love for his students and honest interest in education. He has to be in command of the subject he teaches and the subjects related to his specialization. He has to be capable of innovation and logical analysis. He should be able to play successfully the role of a good example (Alrameedi, 2004). The current times require from the teacher to have a number of innovative merits such as initiation spirit, deep self-confidence in the classroom, good understanding of the personalities of learners, ability to make best use of time for school activities and ability to build up a wide range of relations with other teachers (Alaloosi and Za'abi, 2001).

Hence, the teacher plays an important role in the educational-learning process since he is the cornerstone of the educational situation. Once he is good, the whole society will be good. At his hands doctors, lawyers, engineers 
and many other titles are graduated. Therefore, the teacher should have a high status in our society due to the great role he plays. Teachers are exposed to a lot of stress at work: occupational or psychological stress. Such pressures are the outcome of their interaction with the school educational environment and with society, as their job necessitates. Pressure, defined by (Massa'eed 1992), is a state where an individual feels anxious and worried. This results in imbalance caused by effects from the surrounding local environment.

Alison (1997) defined it as a phenomenon of inability that negatively affects individuals' health. Tartoori and Qudah (2004) defined pressure as a psychological stress resulted from burdens that make an individual unable to work because it exceeds his capabilities, so the feeling of discomfort emerges. Dokhan and Alhajar (2006) defined it as a group of events and situations that lead to a feeling of anxiety. It usually occurs when an individual understands that the requests laid on his shoulders are heavier than what he can hold. Golden (1993) defined this kind of pressure as a physical and psychological state formed when an individual faces environmental events leading to a feeling of discomfort.

Capl (1997) saw that there were many causes behind physical pressures. He points out that worries from evaluation of officials was one cause. Capl argues that pressure decreases in case of increased experience. Harris (1999) pointed to the school management pattern as a factor that forms pressure on teachers. He also found the pattern of relations among teacher to have a big role in generating pressure.

Hawajri (2004) saw that psychological pressure was an outcome of various life burdens. Hipps and Haplin (1991) argue that the major factors contributing to stress on teachers are the many burdens and job responsibilities, the relations between teachers and supervisors, and low salaries. Fore (2002) noted that the major factors generating psychological stress are represented in work pressure, much paperwork, lack of opportunities to progress and promote occupationally.

From the above, we can note that there were many factors that can form stress upon teachers, such as fear from officials, many occupational burdens and responsibilities, and relations inside and outside the school. These stresses have effects on teachers in a way or another.

Aren (2004) argued that teachers who were affected by work stress suffer from states of anxiety, fear and irritation which, in turn, affects their physical and psychological health. This reflects negatively on their level of performance leading to a loss of innovation, decrease of productivity and increase in absenteeism. Gazel (1993) saw that stresses lead to the growth of teachers' absenteeism rate, unwillingness to work and increased cases of early retirement. Zaidan (2003) stated that stresses appear in several forms:

Physical Health: heart attacks, high blood pressure...etc.

Psychological Health: depression, anxiety, irritation, amnesia and low concentration.

Behavior: absenteeism, isolation, hostility.

Organization: low self-esteem, many complaints, corrupt relations at work and low level of productivity.

Omari and Jamal (2004) assured that stress is a major contributor in teachers' hatred for teaching. This affects the level of interaction with students in classrooms and also affects the good relations between teachers and students. Moreover, it stands on the way of motivation students toward innovation.

The topic of psychological pressures on teachers attracted the interest of many researchers. The study of Hussein (1994) aimed at identifying the level of psychological anxiety and its sources in general education in Riyadh. The study sample was composed of 140 male and female teachers. Findings referred to the fact that teachers' anxiety level was within average range with no statistical differences due to teachers' nationality, experience, educational qualifications or the stage of education. The study showed that the most important sources of anxiety are routine and boredom at work, personality formation factor and personal life factor. The most prominent anxiety source that distinguished between anxious and less anxious teachers is personal life. The study of Ezzat and Galal (1997) aimed at recognizing the relation between psychological pressures of elementary school teachers and some variables such as age, gender, experience and trend toward the profession of teaching. The study sample was composed of 90 male and female teachers. The study concluded that there is a significant positive correlation between psychological pressures, age and years of experience. There is also a significant difference in the favor of male teacher when it comes to psychological pressures related to working with elementary education students.

The study conducted by Shafa'i (1998) aimed at comparing the pressures of teaching profession, as realized by elementary stage teachers in Egypt, to the pressures of the following professions: managers of large-sized elementary schools, phone central employees and nurses of big hospitals. The study sample comprised 176 
participants, 46 of which are male and female teachers, 39 are managers, 42 are phone department employees and 49 are female nurses. The descriptive survey approach was used to achieve the study's objectives. The study concluded the following:

Pressures differ from one profession to another. It has been found that teaching profession has higher level of pressure than phone department professions and less than management while it shares the same level with nursing. A significant inverse relation was found between teachers' evaluation of occupational pressures and their educational beliefs. The study made by Mohammed (1999) aimed at revealing the major occupational pressures faced by teachers and at recognizing the differences between genders as for sexual pressure and its rank. The study also aimed at identifying the guidance needs of teachers. The study sample contained 198 male and female teachers selected randomly in accordance to gender and educational stage. Findings revealed the following:

There were a lot of forms for psychological pressures endured by teachers: managerial pressures, student pressures, teaching pressures and pressures related to the relations with colleagues. Managerial pressures turned out to gain the first rank in order, followed by student pressures, and finally colleagues' pressures. There are differences in managerial pressures due to gender. Such differences were in the favor of males while students and colleagues' pressures were found to more stressing on female teachers than male ones. There was no difference between males and females as for teaching pressures.

Metwali (2000) conducted a study to identify psychological pressures and their relations to gender, years of experience and some personality traits of elementary education teacher at Damietta Governorate of Egypt. The study sample consisted of 240 male and female elementary education teachers. Findings revealed significant statistical difference due to gender variable and in favor for female teachers. Findings also pointed that teachers with high level of pressures tend to be anxious, irritated and inefficient at work. In addition, relations to their bosses were negative.

Masha'an (2000) conducted a study to identify the sources of pressure at intermediate education teachers in Kuwait and their relations to the severe psychological disorders. The study sample had 746 male and female teachers. Findings showed difference in the sources of occupational pressures and psychological disorders between the two genders and in the favor for female teachers. Findings also revealed a correlation between sources of occupational pressures and psychological disorders.

The study made by Alkahloot (2006) aimed at revealing psychological pressures and their relation to the performance of technology teachers of high elementary education. The study sample consisted of 66 technology male and female teachers from the two Gazza cities and northern Gazza. To achieve the objectives of the study, the researcher used the school pressures scale and a performance observation questionnaire. Findings pointed that the common psychological pressures among technology teachers have 55 percent. Finding also revealed that the major factor affecting teachers was students' behaviors, followed by relations with managers. No correlation was found between school pressures and the performance of technology teachers.

In the light of the previous studies, the researchers concluded the following:

1- The current study is similar to the previous studies in its focus on psychological pressures endured by teachers.

2- The current study is different from the previous studies in the following:

a- The current study handles psychological pressures endured by social studies teachers while previous studies researched the various specializations.

b- This study presents recommendations to lower pressures on social studies teachers. No previous study had the same objective.

c- This study will reveal whether pressures on social studies teachers have effects upon their performance. No previous study had the same objective.

- For these reasons, the current study is a qualitative addition to the previous studies.

\section{Problem and Questions of the Study}

Social Studies teachers suffer these days from a lot of psychological and occupational pressures either inside or outside school. Such pressures are represented in the behaviors of students, social stresses, decrease of teacher's dignity within society, social disrespect for teachers, low salaries and other pressures that affect the psychology of Social Studies teachers since they are more connective to society. All these pressures affect, in turn, on the students' learning and teachers' performance inside classrooms. Therefore, this study aims at revealing the 
psychological pressures affecting Social Studies teachers at Ma'an education directorate through providing answers to the following questions:

1- What is the level of psychological pressures affecting Social Studies teachers?

2- Do psychological pressures affecting Social Studies teacher differ due to gender?

3- Do psychological pressures affecting Social Studies teacher differ due to years of experience?

4- What are the suggestions of Social Studies teachers to decrease psychological pressures endured?

5- Do psychological pressures endured by Social Studies teachers affect their performance in classrooms?

\section{Significance of Study}

Significance of this study lies in the following:

This study is deemed one of the fist studies for the researchers that search psychological pressures suffered by Social Studies teachers.

1. The results of this study may be used by employees in charge of Ministry of Education through knowing real psychological pressures affecting Social Studies teachers.

2. This study will provide proposals to minimize psychological pressures affected by teachers.

3. This study will disclose whether psychological pressures affecting Social Studies teachers leave effect on their performance.

\section{Definitions of Terms}

- Psychological Pressures: they are defined by researchers that they are the group of influences making stress on Social Studies teachers and affecting their performance inside and outside the class, and they are the pressures mentioned in study instrument (Study Annex).

- Social Studies Teachers: they are all teachers teaching Social Studies subject (History, Geography \& National Education) in Ma'an Directorate of Education in the academic year 2009/2010.

- Ma'an Directorate of Education: it is one of Educational Directorates in southern part of Hashemite Kingdom of Jordon.

\section{Limitations of the Study}

The current study is limited by the following:

1. This study is limited to Social Studies teachers in Ma'an Directorate of Education for academic year 2009/2010

This study is limited to a study instrument prepared by the researchers.

\section{Methods}

\section{Sample of the Study}

The study sample includes (76) teachers (male and female) teaching Social Studies subject (History, Geography \& National Education) in Ma'an Directorate of Education with regard to academic year 2009/2010.

\section{Instrument of the Study}

The instrument of the study based on a questionnaire, and it has been prepared according to the following steps:

1. Reference was made to previous educational literature relating to psychological pressures whether for teachers, managers and students.

2. Reference was made to previous studies relating to psychological pressures and benefiting from its instruments.

3. The question was directed to Social Studies teacher stating "What are the psychological pressures affecting you as a teacher?"

4. In the light of above, list of psychological pressures has been prepared including 39 items of psychological pressures affecting teachers.

5. The instrument has been presented to a group of referees to make sure of its trueness; together with a number of referees were 7 referees who are specialists in teaching techniques, psychology, and sociology to examine the suitability extent of these paragraphs to achieve the target of this study. In addition, they were called upon to determine the clarity extent of paragraphs, and to state their 
opinions as to deletion of repeated or unsuitable paragraphs, and adding any amendments or paragraphs deemed appropriate.

6. After returning the instrument from referees, its final form includes 35 items where repeated and unsuitable paragraphs were deleted.

7. Questionnaire included questions need stylistic answers by Social Studies teachers, which are:

A. What are your suggestions as Social Studies teacher to minimize the percent of psychological pressures?

B. Do psychological pressures, affected by you as Social Studies teacher, have any influence on your performance inside the class?

\section{The Reliability of the Instrument}

The reliability of the instrument was found by Chronbach's Alpha Equation (KR20), and the total reliability coefficient was (0.83)

\section{Applying School Instrument}

The school instrument was applied during the second semester of academic year 2009/2010, and the researchers keened on applying the instrument by using interview method to obtain results featured by trueness and accuracy.

\section{Variables of the Study}

The study includes the following variables:

A. Independent Variables, namely: Social type, including male and females levels

1. Experience which include three categories (1-5 years), (6-10 years) \& (11 years and above).

B. Dependent Variable: Estimation of Social Studies teachers to the levels of psychological pressures affecting them during their work.

\section{Statistical Processing}

To answer the first question arithmetic averages, standard deviations and percentages have been calculated. As for answering second questions, T-test has been used, and to answer the third question the researchers used analysis of variance (one way ANOVA).

\section{Results and Discussions}

\section{First Question: What is the level of psychological pressures affecting Social Studies teachers?}

To answer this question arithmetic (moving) averages, standard deviations have been calculated as indicated in Table (1).

It is indicated from the above Table (1) that the arithmetic average of psychological pressures affecting teachers is equal to (2.36) from (3), with percent $78.66 \%$, and this percent is considered to be high in forming psychological pressures on teachers, together with the most five pressures affecting Social Studies teachers are:

- "Continuous change of school books " with arithmetic average (2.90), and standard deviation (0.37), and this is due to book change, needing teacher to make continuous lessons preparation and books examination, sources and references, and this burdens more time and effort on teachers. Thus, this forms a psychological stress on teachers.

- "Trespassing of students on teachers", with arithmetic average (2.88), and standard deviation (0.43), and this is due to the nature of laws enacted by Jordanian Ministry of Education that prevent the teacher from beating, fearing or looming over students, hence this leads to trespassing of students. Or this may be due to most of teachers' ages, close to students' ages in secondary stage, with less experience to deal with students, so they removed barriers with students and consequently trespassing of students on them. This result is similar to the study of Al-Kahlot (2006).

- "Negative perspective of the society toward teacher", with arithmetic average (2.82), and standard deviation (0.41). This is due to the weakness of teachers' characters at this time. Teachers became confined to the field of their specialization. This matter has a bad influence on teachers and generates negative perspective of society toward teachers, or maybe this is due to trespassing of students and their parents on teachers. This forms a psychological stress on teachers. Moreover, it is due to uncaring 
of teachers toward education, since there are not material and moral motivations, negative perspective of the society may be formed toward them.

- "Low salaries insufficient to meet living needs", with arithmetic average (2.80), and standard deviation (0.47). The researchers confirm that this factor forms a psychological stress on teachers because their salaries are less than salaries of other categories in the society, or they are not enough to meet their living needs. This matter obliged some teachers to practice some behaviors, such as tutoring students; or other business such as trade and taxi driving. All of these matters actually influence the teacher's personality as education job must be sanctified and should be highly esteemed. In addition, the teacher is considered an educator, a leader, a maker of future generations. Thus, he must receive the highest status. This result goes in lines with Hipps and Haplin (1991).

- "Large number of daily class hours" with arithmetic average (2.75), and standard deviation (0.51), and this is confirmed by the two researchers. This is due to the number of class hours of each teacher in a week which is not less than 25 class hours. This means that each teacher delivers five lessons a day, so large number of class hours make psychological stress on him as he spends 6-7 hours a day in the school and the same in lesson preparation, as a result the half day of a teacher is dedicated to teaching and lessons preparation. When we think over low salaries and need of teachers to other work to meet their living needs; all of these matters influence teacher's morals and performance inside a school.

\section{Second Question: Do psychological pressures affecting Social Studies teacher differ due to gender?}

To answer this question, the researchers used T-test as indicated in Table (2). It is indicated from Table (2) that there are differences with statistical significance belonging to gender variable and in the favor of male teachers; which means that male teachers are more vulnerable to psychological pressures than female teachers. This may be due to the fact that male teachers are responsible for their families with regard to providing all necessaries of living fields, so they are affected by psychological pressures more than female teachers whose responsibilities are limited, compared to male. The reason may be due to the nature of calmness dominated in female schools compared to male schools that are dominated by disorders and quarrels on a continuous basis. Thus, the vulnerability of male teachers to pressures is more than females. This result agrees with the study of Azza \& Galal (1997), and disagrees with study of Metwali (2001) and the study of Meshaan (2000).

\section{Third Question: Do psychological pressures affecting Social Studies teacher differ due to years of} experience?

To answer this question we used one way analysis of variance as indicated in Table (3).

It is indicated from Table (3) that there is no statistical significance differences belonging to experience variable. This means that all teachers, with all their experience levels, are affected by psychological pressures: a matter which supports the view that there are psychological pressures on all Social Studies teachers. This result agrees with study results of Hussien (1994).

Fourth Question: What are the suggestions of Social Studies teachers to decrease psychological pressures endured?

To answer this question, open question was directed to Social Studies teachers under study instrument. Furthermore, it has been employed by using interview method and teachers' provision of more proposals to minimize psychological pressures. The most important of these proposals are:

- Increasing salaries of Social Studies teachers to meet modern life needs.

- Diminishing the number of class hours, where the teacher load is no more than fifteen class hours a week.

- Ministry of Education must establish regulations preventing trespassing of students and their parents on teachers.

- Establishing teachers syndicate or union calling for their rights along the lines of other careers.

- Participation of teachers in educational decisions relating to them.

- Decreasing the number of students within the grades.

- Annual teacher report should be made according to students' opinions, not manger or educational supervisor opinion.

- Setting up class hours based on flexible method, where teachers may select time of lessons or class hours that is in conformity with his conditions. 
Fifth Question: Do psychological pressures endured by Social Studies teachers affect their performance in classrooms?

To answer this question, an open question was directed to Social Studies teachers under study instrument. Results pointed out that $96 \%$ of teachers are negatively influenced during their work. In addition, findings indicated that pressures affect them through generating depression, frustration, boredom, and dishonesty toward their work inside the class. This means: the more pressures increased, the more teacher performance decreased. Consequently, pressures negatively affect teacher's psychology. This result agrees with what referred by Aron (2004), Gaziei (1993), Zidan (2003), El-Emari \& Gamal (2000), as well as the study result of Metwali (2000), (El-Meshaan 2000) and El-Kahlot (2006).

\section{Recommendations}

On the basis of study results, the researchers recommended the following:

1. Calling upon Ministry of Education to raise materially and morally the status of teacher in the society.

2. Minimizing teacher school load where no more than maximum eighteen class hours a week so that the number of class hours can not lead to psychological pressure on a teacher.

3. Setting up strict laws preventing trespassing on teachers in schools.

4. Establishing Teachers Syndicate to call for their rights.

\section{References}

Alaloosi, S. \& Za'abi, T. (2001). Creative Teaching. Al-Manhal House, Amman, Jordan.

Ali, S. (2007). The Assets of Public Education. $1^{\text {st }}$ edition. Almaseerah Publishing House, Amman, Jordan.

Alkahloot, E. (2006). School Pressures and its Relationship to Technology Teachers' Performance in the Upper Basic Stage. The First Conference in Alaqsa University, Gaza. Curricula the Reality and Aspirations.

Allison, G, A. (1997). Coping with stress in the principal-ship. Journal of Educational Administration, pp 39-53

Alrameedi, K. (2004). Foundations of Education between Contradiction of Theories and the Failure of Applications. University Student's Library, Kuwait.

Alrashdan, A. \& Ja'aneeni, N. (1994). Introduction to Education. Alshrooq Publishing House, Amman, Jordan.

Aren, J. (2004). Living with the Pressures of Work: How to Overcome the Pressure of Daily Work. Jareer Bookstores, Riyadh, Saudi Arabia.

Capel, S. (1997). Changes in student anxieties and concerns after their first and second teaching practices. Educational Research, 39,211-228.

Dokhan, N. \& Alhajar, B. (2006). Psychological Pressures to the Islamic University Students and Their Relationship to the Psychological Toughness They Have. Islamic Studies Series, Gaza, 14 (2), Pp 369-398.

Ezzat, F. A \& Jalal, N. (1997). Psychological Pressures Among Teachers of Elementary Stage and its Relationship to Some Personal Variables. Egyptian Journal of Psychological Studies, 16, pp 155-184.

Fore, C. Martin, C \& Bender, W. (2002). Teacher Burn out in Special Education: The Causes and the Recommended Solutions. High School Journal, 88 (1), pp (36-45).

Gaziel, H. (1993). Coping with occupational stress Among teachers Across cultural. Comparative education, 29(1), pp 67-77.

Gordan, R, J. (1993). Adiagnostic approach to organizational behavior. Allan \&Bacon: Boston.

Harris, C.A. (1999). The relationship between principal leadership styles and teacher stress in low socioeconomic urban elementary schools as perceived by teachers. D.A.I.60:1911.

Hawajri, A. (2004). The relationship between stress and peptic ulcer. bUnpublished master thesis. University of Jordan. Amman, Jordan.

Hipps, E. Haplin, G. (1991). The Relationship of Focus of Control, Stress Related to Performance - Based Accreditation, and Job Stress to Burn out in Public School Teachers and Principals, Paper Presented at the Annual Meeting of the American Educational Research Association. Chicago. April 3-7.

Hussain, M. (1994). A Study of the Level of Stress and its Sources among Teachers in Public Education in Riyadh. Psychological Studies Journal, 14, 263-285. 
Masa'eed, F. (1993). The Teachers, of public schools source of psychological pressures unpublished master thesis, AL-Najah university Nablus, palestine.

Masha'an, M. (2000). The Sources of Jobs Pressures to the Teachers' in the Intermediate Stage in Kuwait and its Relationship to the Psychosomatic Disorders. Journal of Education, Kuwait University, 28(1), pp 65-96.

Metwali, A. (2000). Psychological Pressures and its Relationship to Gender, Experience and some Personal Attributes to the Teachers of Elementary Stage. Egyptian Journal of Psychological Studies, 10 (April) p125.

Omari, W. \& Jamal, M. (2004). Teachers' Pressures and Anxiety. Al-Ain: University Book House.

Shafa'i, M. (1988). A Contrastive Study Between Teaching Presuures and Their Jobs: Its Relationship to the Teachers' Educational Beliefs. Educational Journal, 12 (48). pp 185-214.

Tartoori, M. \& Qudah, M. (2006). The New Teacher. Teacher's Guide in Effective Health Administration, $2^{\text {nd }}$ Edition. Alhamid Publishing House, Amman, Jordan.

Yusuf, M. (1999). Psychological Pressures among Teachers and Their Need for Guidelines. Journal of Education Research Center. University of Qatar, 15, pp 195-224.

Zaidan, M. (2003). Performance Evaluation and Respond to Crises. Cairo: Arabian Nile Group.

Table 1. Arithmetic averages, standard deviations of psychological pressures in descending order

\begin{tabular}{|l|l|l|l|}
\hline No & Paragraph & Arithmetic Average & Standard Deviation \\
\hline 1 & Continuous change of school books & 2.90 & 0.37 \\
\hline 2 & Trespassing of students on teachers & 2.88 & 0.43 \\
\hline 3 & $\begin{array}{l}\text { Negative perspective of the society toward } \\
\text { teacher }\end{array}$ & 2.82 & 0.41 \\
\hline 4 & $\begin{array}{l}\text { Low salaries and its insufficiency to meet } \\
\text { living needs. }\end{array}$ & 2.80 & 0.47 \\
\hline 5 & Large number of daily class hours & 2.75 & 0.51 \\
\hline 6 & Administrative predominated methods & 2.73 & 0.52 \\
\hline 7 & Curricula longevity and complexity & 2.68 & 0.52 \\
\hline 8 & Continuous change of educational policies & 2.67 & 0.52 \\
\hline 9 & $\begin{array}{l}\text { Unsuitability of my abilities toward education } \\
\text { job }\end{array}$ & 2.65 & 0.55 \\
\hline 10 & $\begin{array}{l}\text { Bad relationships among teachers inside } \\
\text { school }\end{array}$ & 2.63 & 0.58 \\
\hline 11 & $\begin{array}{l}\text { Withholding teacher from all powers inside } \\
\text { class or grade }\end{array}$ & 2.60 & 0.59 \\
\hline 12 & $\begin{array}{l}\text { Inability of teacher to match with education } \\
\text { field development }\end{array}$ & 2.59 & 0.59 \\
\hline 13 & Insufficiency of filed training of teachers & 2.58 & 0.61 \\
\hline 14 & $\begin{array}{l}\text { Nepotism and patronage controlled teacher } \\
\text { with his leaders. }\end{array}$ & 2.57 & 0.61 \\
\hline 16 & Large number of students in the grade & 2.56 & 0.66 \\
\hline 17 & Professional inactivity of teacher & 2.46 & 0.72 \\
\hline 18 & Long period of work in a school & 2.39 & 0.73 \\
\hline 19 & Long period of teacher service & 2.34 & 0.80 \\
\hline 20 & Overburdening teacher with routine works & 2.31 & 0.26 \\
\hline 21 & Uncooperative work of teacher & & 0.70 \\
\hline 22 & Inexistence of syndicate for teachers & 2.39 \\
\hline
\end{tabular}




\begin{tabular}{|l|l|l|l|}
\hline 23 & Littleness of teacher time with large duties & 2.25 & 0.67 \\
\hline 24 & No job promotion provided to teachers & 2.22 & 0.68 \\
\hline 25 & $\begin{array}{l}\text { Education job not meeting my ambitions as } \\
\text { teacher }\end{array}$ & 2.15 & 0.81 \\
\hline 26 & Daily routine and boredom for a teacher & 2.11 & 0.84 \\
\hline 27 & $\begin{array}{l}\text { Inexistence of freedom and independence in } \\
\text { education job }\end{array}$ & 2.10 & 0.79 \\
\hline 28 & $\begin{array}{l}\text { Large number of weak level students inside the } \\
\text { class }\end{array}$ & 2.09 & 0.82 \\
\hline 29 & $\begin{array}{l}\text { Not contributing teacher in curricula } \\
\text { composition }\end{array}$ & 2.02 & 0.83 \\
\hline 30 & $\begin{array}{l}\text { Not contributing teacher in educational } \\
\text { curricula }\end{array}$ & 1.98 & 0.82 \\
\hline 31 & Interfering of patents in teacher works & 1.92 & 0.51 \\
\hline 32 & Not encouraging teacher by administrations & 1.88 & 0.78 \\
\hline 33 & Non-interaction of students with teacher & 1.80 & 0.78 \\
\hline 34 & Inexistence of remuneration for teachers & 1.55 & 0.68 \\
\hline 35 & $\begin{array}{l}\text { Not providing necessary capabilities for } \\
\text { teaching in schools. }\end{array}$ & 1.42 & 0.61 \\
\hline & Total & 2.36 & 0.32 \\
\hline
\end{tabular}

Table 2. Results of T-test to know the influence of gender variable on psychological pressures

\begin{tabular}{|l|l|l|l|l|l|}
\hline & Gender & $\begin{array}{l}\text { Arithmetic } \\
\text { Average }\end{array}$ & $\begin{array}{l}\text { Standard } \\
\text { Deviation }\end{array}$ & $\begin{array}{l}\text { Freedom } \\
\text { Degree }\end{array}$ & $\begin{array}{l}\text { Significance } \\
\text { Level }\end{array}$ \\
\hline $\begin{array}{l}\text { Psychological } \\
\text { Pressures }\end{array}$ & Male & 90.30 & 8.26 & 76 & 0.000 \\
\cline { 2 - 4 } & Female & 79.60 & 11.01 & & \\
\hline
\end{tabular}

Table 3. Results of using one way analysis of variance test to know the influence of experience variance

\begin{tabular}{|l|l|l|l|l|l|}
\hline Source of Variance & $\begin{array}{l}\text { Sum of } \\
\text { squares }\end{array}$ & Mean Squares & $\begin{array}{l}\text { Degree of } \\
\text { Freedom }\end{array}$ & F Value & $\begin{array}{l}\text { Significance } \\
\text { Level }\end{array}$ \\
\hline $\begin{array}{l}\text { Psychological Pressures between } \\
\text { groups }\end{array}$ & 71.726 & 35.863 & 2 & 273 & 0.762 \\
\hline Within groups & 9582.37 & 131.265 & 73 & 75 & \\
\hline Total & 9654.10 & & 75 & \\
\hline
\end{tabular}

